Dept. of Theriogenology,

Fac of Vet. Med., Assiut University.

\title{
THE RELATIONSHIP BETWEEN OXIDANTS / ANTIOXIDANTS IMBALANCE AND POSTPARTUM FERTILITY IN CATTLE \\ (With 2 Tables and 2 Figures)
}

\section{By}

\section{G.A. MEGAHED; S.E.M. ALGHANDOUR*; R.H. OTHMAN* and F.A. EL-ZOHERY* \\ * Animal Reproduction Research Institute}

(Received at 20/9/2006)

علاقة عدم توانت الأكسدة و مضادلات الأكسدة بالخصوبة في فترة مـا بعد الأبقال

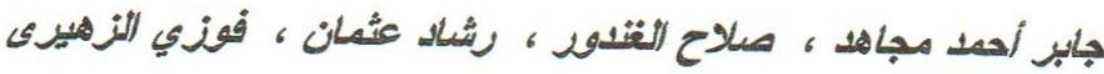

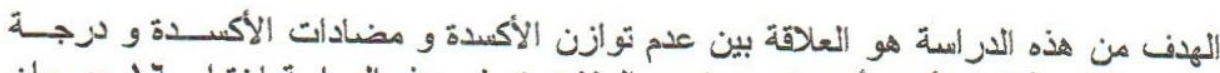

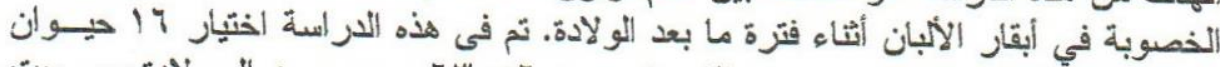

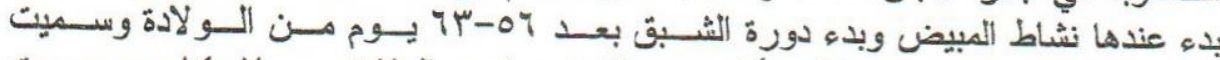

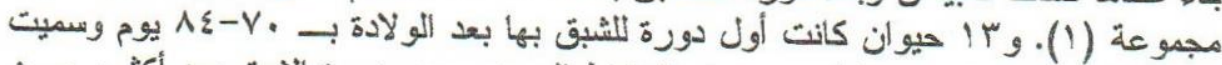

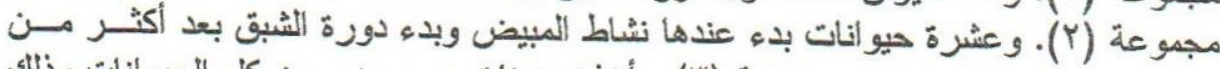

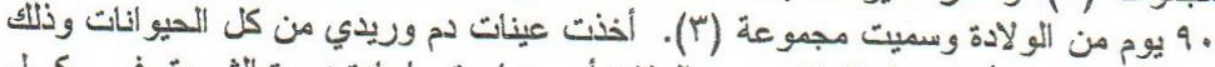

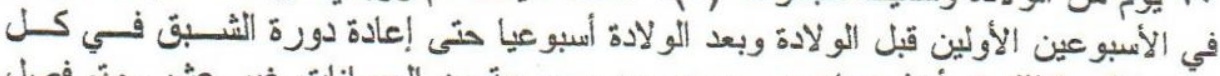

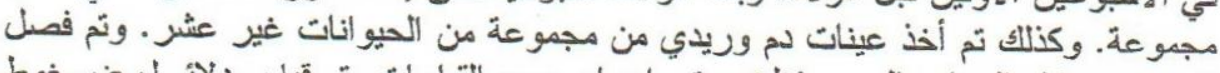

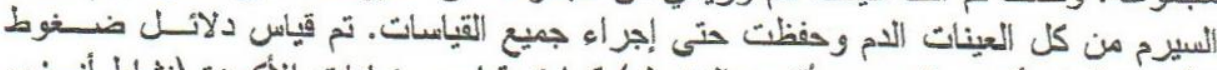

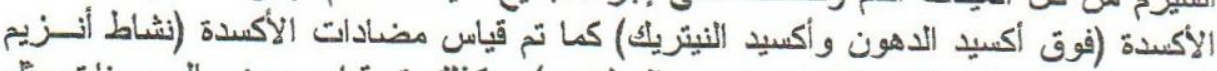

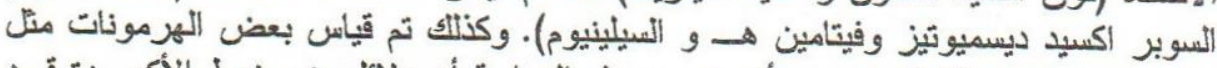

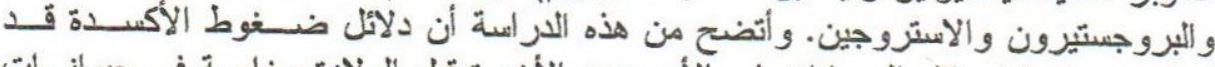

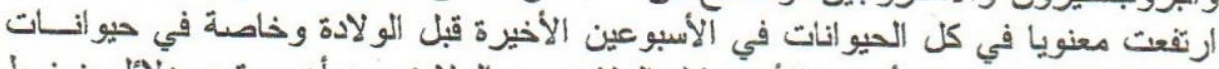

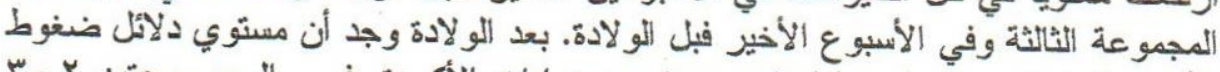

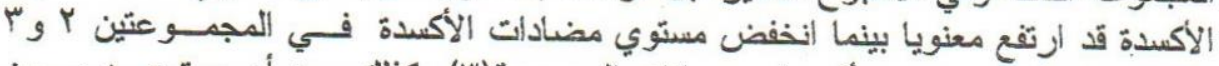

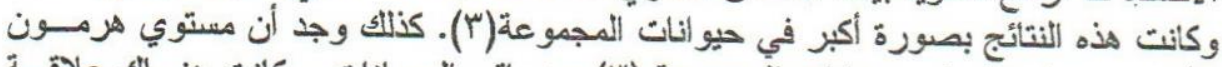

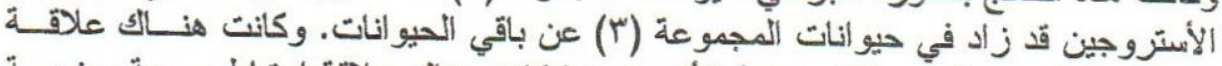

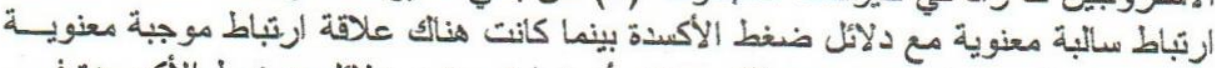

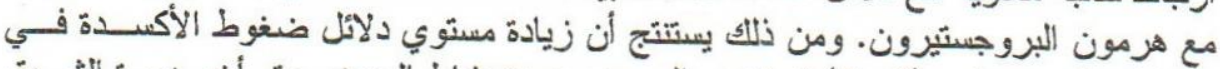

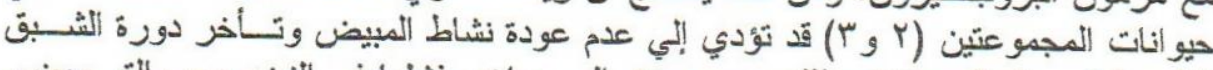

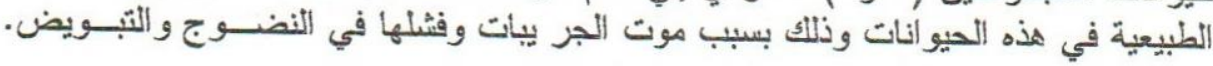




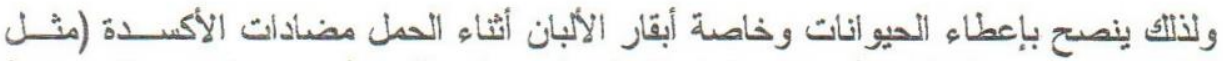

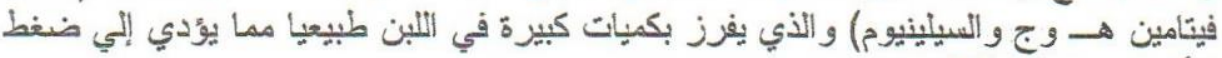
الأكسدة وزينادة دلائلها.

\section{SUMMARY}

The objective of this study was to determine the relationship of postpartum oxidative stress and the ovarian anestrus in the dairy cows. Sixteen cows showed normal ovarian cyclicity (normal estrous cycle) detected after 56-63 days postpartum and kept as G1. Thirteen cows showed ovarian cycle after 70-84 days postpartum, G2 and other ten animals showed marked delayed in the ovarian cyclicity more than 90 days, G3. Venous blood samples were taken weekly from all animals in the last two weeks of pregnancy and in postpartum period as well as, sera of blood samples were kept for measuring all parameters. Another blood samples from ten non-pregnant cows in diestrus were taken. The oxidative stress (lipid peroxides and nitric oxide), antioxidants (superoxide dismutase, vitamin $\mathrm{E}$ and selenium), as well as estradiol-17 $\beta$ and progesterone were measured in all animals. In prepartum, lipid peroxides as well as nitric oxide were increased in the last week of pregnancy. In postpartum the preoxidative indices were elevated in the animals of $\mathrm{G} 3$ while antioxidants were decreased significantly in $\mathrm{G} 3$ and to some extend in G2. Estradiol-17 $\beta$ hormone levels were increased significantly in animals of G3 and it was negatively significant correlated with LPO and NO. While progesterone levels were positively significant correlated with antioxidants in the animals of G3. The oxidative stress in these animals may be led to follicular damage and failure of maturation and ovulation. It was concluded from this study that excess free radical production may be play a role in the prolongation of the postpartum anestrus in dairy cows. These may be due to exhaustion of antioxidant system in milk production. Therefore, it was advise to supplement the dam with antioxidants during the late stage of pregnancy and in the postpartum period to stimulate the normal ovarian activity.

Key words: Antioxidants, Oxidative stress, Vitamin E, Selenium, Prepartum, Postpartum, SOD, Nitric Oxide, Lipid Peroxidation.

\section{INTRODUCTION}

Cattle production may be divided into two sectors, dairy and beef production. The main objective in the dairy herd is to produce milk as 
economically as possible. Reproduction is a vital factor in determining the efficiency of animal production (Ball and Peters, 2004). Reproduction efficiency can be described as a measure of the ability of a cow to become pregnant and produce viable off-spring. Infertility or sub-fertility are varying degrees of aberration from typical levels of reproductive performance. Reproductive performance of cows affects the efficiency of milk production in the herd because of its influence on the calving to service interval, calving pattern, length of lactation and culling rate (Roche, et al., 1992).

Parturition is followed by a period of ovarian inactivity and sexual quiescence before reproductive cycle recommence. Nutrition plays an important role on the beginning of the reproductive cycles (Borghese, et al., 1997). The postpartum anestrus period is the time after parturition that is necessary for recuperation and reorganization of the brain and reproductive organs. Normally the postpartum interval is 60 70 days in dairy cows.

The antioxidants vitamins (e.g.vitamin E) is important for improve the fertility of the dairy cows (Allison and Laven, 2000). In late pregnancy, the production of free radicals was increased (Toescu, et al., 2002). These elevation in free and increasing in oxidative damage may involved in the of parturition, but the over increase in the oxidative process after parturition may be led to placental retention and/or postpartum infertility. Selenium (Se) and vitamin E are considerable antioxidant agents. Se is an essential co-factor for the enzyme glutathione peroxide which is vital to prevent the production of free radicals (Basini, et al., 1996) as well as, Se catalyses the reduction of peroxides to less harmful hydroxyl acids in the cytoplasm. Moreover, vitamin $\mathrm{E}$ is localized in the cell membranes as a biological antioxidant. If this protective function of vitamin $\mathrm{E}$ and $\mathrm{Se}$ fails, the increased quantities of free radical and may lead to the damage of biological membranes and cell death.

The reactive oxygen species have been implicated as major initiators of tissue damage and can up-regulate enzyme activity, signal transcription, and gene expression may be apoptotic genes (Palmer and Paulson, 1977, Sen and Packer 1996). Antioxidant defenses made up of intracellular and extracellular components work together to obtain an optimal redox balance. Reactive oxygen species play a number of significant diverse roles in female reproductive biology including uterine environment, oocyte maturation and ovulation, corpus luteum function and regression (Riley and Behrman, 1991 and Megahed et al., 2002). 
Oxyradicals in the ovarian tissues mar affected the growth of the follicles and cell-permeant antioxidants inhibit spontaneous resumption of meiosis, which may implicated a role of oxygen radicals in oocyte maturation (Behrman et al., 2001).

In the present work we will consider the relationship between oxidants/antioxidant imbalance and postpartum hormonal condition in the cattle as well as their possible interactions with fertility.

\section{MATERIALS and METHODS}

1. Animals and their managements.

Forty-five pregnant and ten non-pregnant (in luteal phase of estrous cycle) dairy cows were used in this study. The age of the animals ranged from 4-7 years and their parity was 2-4. They were housed in Assiut village under the same ordinary or the same feeding and management conditions. In addition, the animals were given a free access to drinking water. The animals were selected at the last two weeks prepartum. Following parturition, the cows were allowed for suckling. Calves were removed about 3 days after birth. Milking was carried twice daily. The animals were observed twice daily for estrus. Thirty-nine out of 45 cows shows estrus after observation. According to observable heat, the animals were divided into 3 groups. The 1st group $(\mathrm{G} 1, \mathrm{n}=16)$, which considered an animals shows the first estrus after 5663 days postpartum. Second group (G2, n=13), where the animals shows the first estrus after 70-84 days postpartum as well as the animals shows the first estrus after more than 90 days postpartum were considered as 3 rd group $(\mathrm{G} 3, \mathrm{n}=10)$. The animals calved in the period between March and may as well as the annual average value of air temperature and relative humidity were $39.3^{\circ} \mathrm{C}$ and $69.2 \%$ respectively. All animal were inseminated naturally at the first detectable estrus after calving and observed again for return heat then examined rectally 45-60 days after insemination for pregnancy. The animals, which returned again to heat were inseminated again.

2. Blood sampling.

Blood samples were taken weekly (prepartum and postpartum) by via jugular venipuncture and collected in a clean sterile centrifuged tubes to separate serum for all measurements investigated. The time of collection of all samples was subsequently standardized from the time of parturition taken as day 0 . The blood samples of the non-pregnant animals were taken in diestrus phase. Serum was pipetted into glass vials and stored at $-20^{\circ} \mathrm{C}$ until assay for Biochemical and hormones. 


\section{Biochemical analysis.}

Lipid peroxidation (LPO) was measured as thiobarbituric acid reactive substances (TBARS). The product of the reaction between malondildehyde and thiobarbituric acid was measured as describes by Buege and Aust (1977), with using 1, 1, 3, 3- tetramethoxypropane as standard. Nitric oxide (NO) levels were measured as nitrate concentration after reduction of nitrate to nitrite with Griees reagent. The reaction was measured using sodium nitrite as standard according to Ding et al. (1988). Superoxide dismutase (SOD) activity was estimated according to its ability to inhibit the autoxidation of epinephrine at alkaline medium according to Misra and Fridovich (1972). Vitamin E was determined according to Aebischer et al. (1999) by using a Hewlett Packard 1090 automated HPLC equipped with diode array and fluorescence detectors. The type of used column was a Primesphere C18-HC, $250 \times 4.6 \mathrm{~mm}, 5 \mu \mathrm{m}$ paticle size (Phenomenex), eluted with acetonitrite : tetrahydrofuran : methanol 1:1\% (w : v) ammonium acetae (684: 220: 68: 28) at a flow rate of $0.7 \mathrm{~mL} / \mathrm{min}$. Serum selenium was quantified according to Ericson et al. (1986) using graphite furnace atomic absorption spectrophotometer (BE 744A).

4. Hormonal assay.

Progesterone $\left(\mathrm{P}_{4}\right)$ and estradiol-17B $\left(\mathrm{E}_{2}\right)$ concentrations in the blood serum were determined by commercial ELISA kits (BIOSURCE, EUROPS S.A) and automatic ELISA reader Anthos, 2000.

5. Statistical analysis.

Data were expressed as the mean \pm SEM for all parameters. The data were analyzed by using Analysis of Variance (ANOVA) with Bonferroni's post-test. The data of animals in prepartum and nonpregnant were analyzed using ANOVA and post-test Dunnett for multiple comparisons with confidence intervals at $90 \%$ as appropriate. The correlation coefficient with Pearson test were done between LPO, $\mathrm{NO}$ and other parameter. Results were considered significant at $\mathrm{P}>0.05$ or less. The graphs of these parameters were done using Prism 3 Graph Pad computer programmed.

\section{RESULTS}

The obtained results are presented in Tables 1,2 and Figures 1 and 2. Table 1 shows that LPO levels were increased significantly $(\mathrm{P}<0.01$ and $\mathrm{P}<0.05)$ in $\mathrm{G} 2$ and $\mathrm{G} 3$ during $2^{\text {nd }}$ and $1^{\text {st }}$ week before 
parturition when compared with non-pregnant cows. While it was elevated significantly $(\mathrm{P}<0.05)$ in $1^{\text {st }}$ week before parturition in $\mathrm{G} 1$ but increased non-significantly in G2 when compared with non-pregnant cows. The nitric oxide (NO) levels were increased significantly $(\mathrm{P}<0.01)$ in animals of $\mathrm{G} 3$ before parturition by $2^{\text {nd }}$ and $1^{\text {st }}$ weeks, however it increased significantly $(\mathrm{P}<0.05)$ in $\mathrm{G} 1$ and $\mathrm{G} 2$ in comparison with nonpregnant animals. SOD levels were decreased significantly $(\mathrm{P}<0.5$, $\mathrm{P}<0.01$ ) in animals of $\mathrm{G} 3$ at $2^{\text {nd }}$ and $1^{\text {st }}$ week before parturition respectively. Moreover, it was increased significantly $(\mathrm{P}<0.05)$ at both $2^{\text {nd }}$ and $1^{\text {st }}$ week before parturition in the animals of G2. In G1, SOD levels were decreased non-significantly in comparison to non-pregnant animals. Looking to the same table, vitamin E and selenium levels recorded a significant $(\mathrm{P}<0.01)$ decreased in all groups at $1^{\text {st }}$ week before parturition.

Table 2 shows that the correlation between oxidative stress (LPO, NO) and antioxidants (SOD, Selenium and vitamin E) with progesterone $(\mathrm{P} 4)$ and estradiol-17ß $\left(\mathrm{E}_{2}\right)$ in groups of animals during postpartum. LPO were negative correlated with SOD activities, vitamin $\mathrm{E}$ and selenium in all groups of animals. In G1 and G2, LPO had a nonsignificantly negative correlation $(r=-0.1$ and $r=-0.2)$ with SOD, however, in $\mathrm{G} 3$, it became significantly $(\mathrm{P}<0.01)$ negative correlation $(\mathrm{r}$ $=-0.65)$. There were a significantly $(\mathrm{P}<0.01)$ negative correlation $(\mathrm{r}=-$ $0.71,-0.64,-0.77$ ) between LPO and vitamin $\mathrm{E}$, selenium and $\mathrm{E}_{2}$ in $\mathrm{G} 3$ respectively, but the correlation between $\mathrm{LPO}$ and $\mathrm{P}_{4}$ was positively significant $(P<0.05)$ correlation $(r=0.58)$ in $G 3$. The same recorded results were noticed between $\mathrm{NO}$ and $\mathrm{SOD}$ activities, vitamin $\mathrm{E}$, selenium, $\mathrm{E}_{2}$ and $\mathrm{P}_{4}$ in $\mathrm{G} 3$ expect, the significant results between NO with selenium became $\mathrm{P}<0.05$ and $\mathrm{P}<0.01$ in $\mathrm{E}_{2}$. Moreover, it became $\mathrm{P}<0.01$ in case of $\mathrm{P}_{4}$.

Fig. 1 shows that the levels of LPO, NO, SOD, vitamin E and selenium hormone in all the three groups of animals (G1, G2 and G3) from the first week postpartum ended by the week of ovarian resumption. Generally, LPO levels were significantly increased $(\mathrm{P}<0.01)$ in $\mathrm{G} 3$ versus $\mathrm{G} 1$ and $\mathrm{G} 2$. At the first week after parturition, the levels of LPO were $0.97 \pm 0.12$ (in G1), $1.89 \pm 0.1$ (in G2) and $3.76 \pm 0.45 \mathrm{nM} / \mathrm{ml}$ (in G3). These obtained results decreased significantly $(\mathrm{P}<0.01)$ near the weeks of ovarian resumption in each group ( $8^{\text {th }}$ and $9^{\text {th }}$ week in $\mathrm{G} 1,11^{\text {th }}$ and $12^{\text {th }}$ week in G2 and $14^{\text {th }}$ and $15^{\text {th }}$ week in G3). The same recorded results of NO were in each group were observed. The levels of antioxidant system in this study (SOD, vitamin E and selenium) were 
decreased significantly $(\mathrm{P}<0.05)$ at $1^{\text {st }}$ week after delivery. Furthermore, these recorded results were increased significantly $(\mathrm{P}<0.01)$ near the weeks of ovarian resumption in each group ( $8^{\text {th }}$ and $9^{\text {th }}$ week in GI, $11^{\text {th }}$ and $12^{\text {th }}$ week in G2 and $14^{\text {th }}$ and $15^{\text {th }}$ week in G3).

Fig. 2 shows that the concentrations of $E_{2}$ and $P_{4}$ were fluctuated during postpartum period. The concentrations of $E_{2}$ were increased significantly $(\mathrm{P}<0.01)$ in animals of $\mathrm{G} 1$ and $\mathrm{G} 2$ and significantly $(\mathrm{P}<0.05)$ in $\mathrm{G} 3$ near the weeks of ovarian resumption in each group. While $\mathrm{P}_{4}$ decreased significantly $(\mathrm{P}<0.01)$ in all groups near the weeks of ovarian resumption.

Table 1: The levels of oxidative stress (lipid peroxidation LPO, nitric oxide NO) and antioxidants (SOD, Selenium and vitamin E) in groups of animals during the last two weeks of prepartum and its comparison with levels in non-pregnant cows $(n=10)$.

\begin{tabular}{|c|c|c|c|c|c|c|c|}
\hline & \multirow{2}{*}{$\begin{array}{c}\text { non- } \\
\text { pregnant } \\
\text { cows }\end{array}$} & \multicolumn{3}{|c|}{$2^{\text {nd }}$ week prepartum } & \multicolumn{3}{|c|}{$1^{\text {st }}$ week prepartum } \\
\hline & & $\underset{(n=16)}{G 1}$ & $\begin{array}{c}\mathrm{G} 2 \\
(\mathrm{n}=13)\end{array}$ & $\begin{array}{c}\mathrm{G} 3 \\
(\mathrm{n}=10)\end{array}$ & $\begin{array}{c}G 1 \\
(n=16)\end{array}$ & $\begin{array}{c}G 2 \\
(n=13)\end{array}$ & $\begin{array}{c}\mathrm{G} 3 \\
(\mathrm{n}=10)\end{array}$ \\
\hline $\begin{array}{c}\mathrm{LPO} \\
(\mathrm{nM} / \mathrm{ml})\end{array}$ & $1.08 \pm 0.07$ & $1.82 \div 0.07$ & $2.34 \pm 0.11^{\circ}$ & $2.55 \pm 0.25^{\circ}$ & $2.17 \pm 0.14^{\circ}$ & $2.64 \pm 0.35^{\circ *}$ & $2.8 \pm 0.58^{\circ *}$ \\
\hline $\begin{array}{c}\mathrm{NO} \\
(\mathrm{nM} / \mathrm{ml}) \\
\end{array}$ & $23.63 \pm 0.91$ & $29.31 \pm 0.31^{\circ}$ & $27.58 \pm 0.57^{\circ}$ & $30.55 \pm 0.65^{* *}$ & $29.74 \pm 0.48^{\circ}$ & $27.95 \pm 0.65^{\circ}$ & $31.39 \pm 0.37^{* *}$ \\
\hline $\mathrm{SOD}(\mathrm{U} / \mathrm{ml})$ & $10.63 \pm 1.01$ & $10.26 \pm 0.36$ & $9.27 \pm 0.53^{\circ}$ & $8.39 \pm 0.58^{\circ}$ & $10.58 \pm 0.55$ & $9.06 \pm 0.58^{\circ}$ & $4.97 \pm 0.12^{\circ 0}$ \\
\hline $\begin{array}{l}\text { Vitamin E } \\
(\mu \mathrm{g} / 100 \mathrm{ml})\end{array}$ & $60.8 \pm 1.55$ & $59.57 \pm 0.76$ & $58.87 \pm 0.25^{\circ}$ & $58.06 \pm 0.21^{\circ}$ & $56.18 \pm 0.25^{\circ \bullet}$ & $53.94 \pm 0.55^{\circ *}$ & $53.21=0.23^{\circ *}$ \\
\hline $\begin{array}{l}\text { Selenium } \\
(\mu \mathrm{g} / 100 \mathrm{ml})\end{array}$ & $8.9 \pm 0.12$ & $8.28 \pm 0.41$ & $7.82 \pm 0.32^{\circ}$ & $6.40 \pm 0.83^{\circ "}$ & $5.54 \pm 0.45^{\circ *}$ & $4.66 \pm 0.65^{\circ}$ & $4.07 \pm 0.32^{2 *}$ \\
\hline
\end{tabular}

* significant at $\mathrm{P}<0.05 . \quad{ }^{* *}$ significant at $\mathrm{P}<0.01$.

No letter means non-significant.

Table 2: The correlation between oxidative stress (lipid peroxidation LPO, nitric oxide NO) and antioxidants (SOD, Selenium and vitamin E) with progesterone $\left(\mathrm{P}_{4}\right)$ and estradiol-17B $\left(\mathrm{E}_{2}\right)$ in groups of animals during postpartum.

\begin{tabular}{|c|c|c|c|c|c|c|}
\hline & \multicolumn{3}{|c|}{ LPO } & \multicolumn{3}{c|}{ NO } \\
\hline & G1 & G2 & G3 & G1 & G2 & G3 \\
\hline SOD & -0.10 & -0.20 & $-0.65^{* *}$ & -0.04 & -0.15 & $-0.56^{*}$ \\
\hline Vit. E & -0.01 & $-0.51^{*}$ & $-0.71^{* *}$ & -0.16 & $-0.39^{*}$ & $-0.77^{* *}$ \\
\hline Sel. & -0.02 & $-0.41^{*}$ & $-0.64^{* *}$ & -0.25 & $-0.58^{*}$ & $-0.46^{*}$ \\
\hline E $_{2}$ & +0.13 & +0.51 & $-0.79^{* *}$ & -0.17 & -0.32 & $-0.7^{* *}$ \\
\hline P $_{4}$ & +0.11 & -0.30 & $+0.58^{*}$ & +0.40 & +0.41 & $+0.6^{* *}$ \\
\hline
\end{tabular}

* significant at $\mathrm{P}<0.05 . \quad{ }^{* *}$ significant at $\mathrm{P}<0.01$.

No letter means non-significant. 

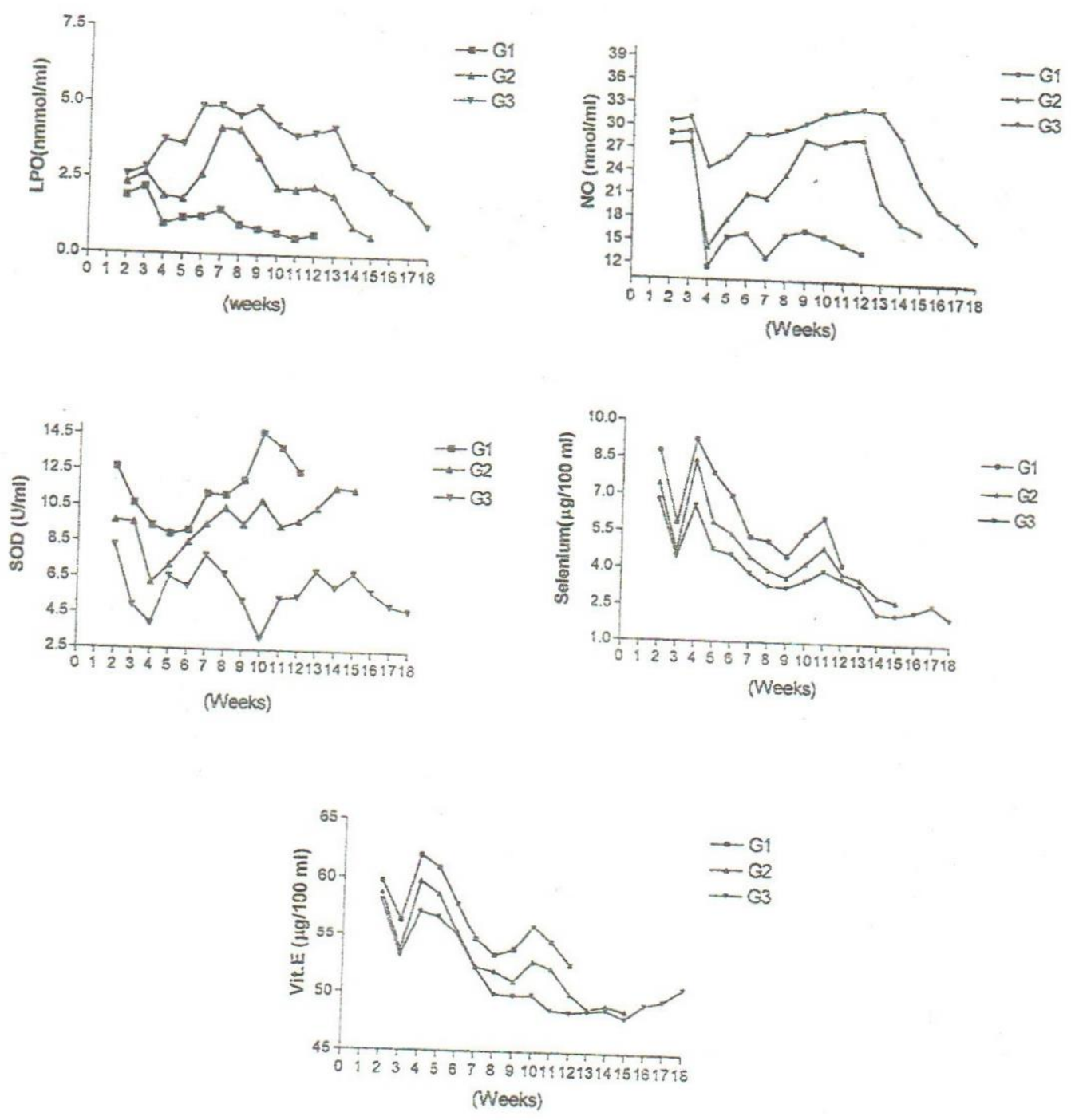

Fig. 1: Comparison between oxidative stress (lipid peroxidation LPO, nitric oxide NO) and antioxidants (SOD, Selenium and vitamin E) in groups of animals during the last two weeks of prepartum and postpartum period.

* Weeks 2,3 means a $2^{\text {nd }}$ and $1^{\text {st }}$ week before parturition.

* Weeks 4 to 18 means $1^{\text {st }}$ to $15^{\text {th }}$ week postpartum.

* Ovarian resumption completed after 56-63 days in G1, 70-84 days in $\mathrm{G} 2$ and more than 90 days in G3. 

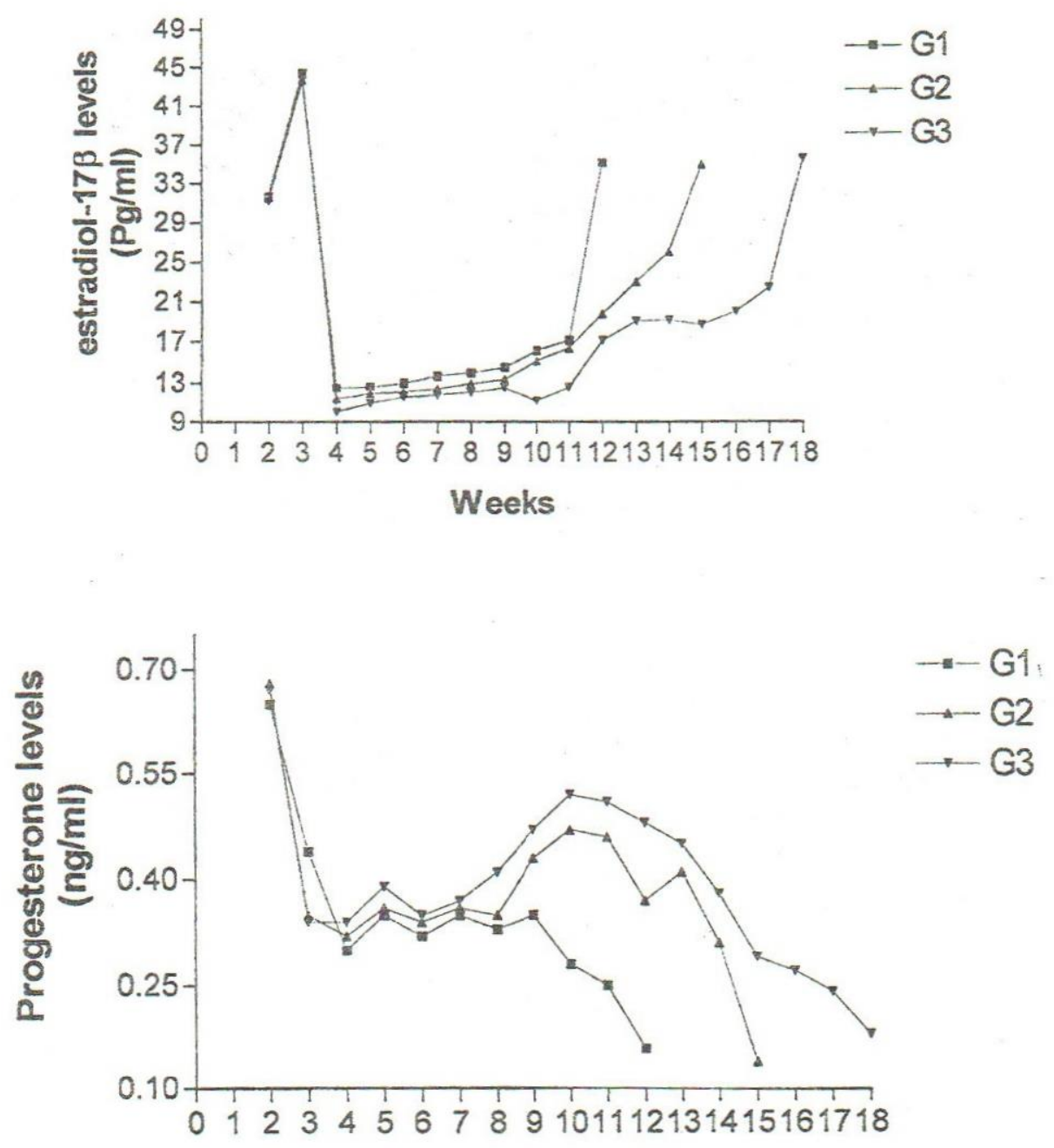

Weeks

Fig. 2: Levels of estradiol $-17 ß(\mathrm{pg} / \mathrm{ml})$ and progesterone $(\mathrm{ng} / \mathrm{ml})$ in groups of animals during the last two weeks of prepartum and postpartum period.

* Weeks 2,3 means a $2^{\text {nd }}$ and $1^{\text {st }}$ week before parturition.

* Weeks 4 to 18 means $1^{\text {st }}$ to $15^{\text {th }}$ week postpartum.

* Ovarian resumption completed after 56-63 days in G1, 70-84 days in $\mathrm{G} 2$ and more than 90 days in G3. 
circulation levels of gonadotropine and steroidogensis (Abou-Seif, and Youssef, 2001).

Free radicals stimulate apoptosis in ovarian tissues and causes follicular atresia in ovary and the antioxidants including estradiol reduced the apoptotic cells by scavenger of the free radical (Murdoch, 1998). The relation between apoptosis and oxidants/antioxidants imbalance were established. Caspase- 3 apoptotic enzymes were induced by free radical production and it stimulate apoptosis in follicular cells on ovarian tissues (Boone and Tsang 1998). There is a link between bcl-2 antiapoptotic gene and oxidative stress in cells. Oxygen free radicals involved in the process of granulosa cells apoptosis during atresia (Tilly and Tilly, 1995). They reported that oxidative stress inhibited the expression of bcl-2 gene. Moreover, they found that gonadotropin mediated follicular survival through enhanced expression of antioxidants. Oxidative stress to follicles inhibited the ability of FSH to prevent apoptosis in granulosa cells (Tilly and Tilly, 1995).

One could be concluded that the prolongation of postpartum anoestrus in dairy cows controlled by many factors and one from these factors may be oxidative stress and exhaustion of the antioxidants, particularly in dairy cows. This may impair of follicular growth and failure to produce fertile cycle. Therefore it was advise to supplement the dam with antioxidants during the late stage of pregnancy and in the postpartum period to stimulate the normal ovarian activity and cyclicity.

\section{REFERENCES}

Abou-Seif, M.A. and Youssef, A.A. (2001): Oxidative stress and male IGF-1, gonadotropin and related hormones in diabetic patients. Clin. Chem. 39: 618-23.

Aebischer, C.P.; Schierle, J. and Schuep, W. (1999): Simultaneous determination of retinol, tochopherols, carotene, lycopene and xanthophyllus in plasma by means of reversed-phase highperformance liquid chromatography. Methods Enzymol., 299: 348-362.

Allison, R.D. and Laven, R.A. (2000): Effect of vitamin E supplementation on the health and fertility of dairy cows: a review. Vet. Res. 147: 703-708.

Baker, H. and Frank, O. (1968): Clinical vitaminology, Wiley, New York, p 1972. 
Basini, G.; Baratta, M.; Grasselli, F.; Bussolati, S. and Tamanini, C. (1996): Selenium increase estradiol-17 $\beta$ production in bovine granulose cells. J. Reprod. Fertil., (Supplement), 38: 25.

Ball, P.J. and Peters, A.R. (ed) (2004): Reproductive efficiency in cattle. IN: Reproduction in Cattle. $3^{\text {rd }}$ Ed., Blackwell publishing, pp. $1-12$.

Behrman, H.R.; Kodaman, P.H.; Preston, S.L. and Gao, S. (2001): Oxidative stress and the ovary. J. Soc. Gynecol Investig., 8: S40-2.

Boone, D.L. and Tsang, B.K. (1998): Caspase-3 in the rat ovary: localization and possible role in follicular atresia and luteal regression. Biol Reprod; 58(6):1533-1539.

Borghese, A.; Barile, V.L.; Ficco, G.; Galasso, A.; Marchior, E. and Terzano, G.M. (1997): Feeding system effect on reproduction performances in buffla0 heifers. V. World Buffalo Congr., Caserta, Italy. Pp. 378-382.

Buege, J.A. and Aust, S.D. (1977): Microsomal lipid peroxidation In: Methods in enzymology eds. Fleischer S. and Pocker L. Vol. 52, pp.302-310. Academic press, New York.

Ding, A.H.; Nathan, C.F. and Stuchr, D.J. (1988): Release of reactive nitrogen intermediates and reactive oxygen intermediate from mouse peritoneal macrophages. Comparison of activating cytokines and evidence for independent production. J. Immun. 141, 2407-2412.

Ericson, S.P.; Mchalsky, M.L.; Rabinow, B.E.; Kronholm, K.G.; Arceo, C.S.; Weltzer, J.A. and Ayd, S.W. (1986): Sampling and analysis techniques for monitoring serum for trace elements. Clin. Chem., 32: 1350- 1356.

Fainaru, O.; Almog, B.; Pinchuk, I.; Kupferminc, M.J.; Lichtenberg, D. and Many, A. (2002): Active labour is associated with increased oxidisibility of serum lipids ex vivo. BJOG. 109 (8): 938-41.

Jensen S. K., Johannsen A. K. and Hermansen J. E. (1999): Quantitative secretion and maximal secretion capacity of retinol, betacarotene and alpha- tocopherol into cows' milk. J. Dairy Res 66: 511-522.

Lachili B., Faure H., Smail A., Zama N., Benlatreche C., Favier A. and Roussel A. M. (1999): Plasma vitamin A, E, and beta-carotene levels in adult postpartum Algerian women. Int. J. Vitam Nutr Res., 69(4): 239-42. 
Liu, R.H.; Li, Y.H.; Jiao, L.H.; Wang, X.N.; Wang, H. and Wang, W.H. (2002a): Extracellular and intracellular factors affecting nuclear and cytoplasmic maturation of porcine oocytes collected from different sizes of follicles. Zygote 10: 253-60.

Liu, Y.; Shimizu, I.; Omoya, T.; Ito, S.; Gu, X.S. and Zuo, J. (2002b): Protective effect of estradiol on hepatocytic oxidative damage. World J. Gastroenterol 8: 363-6.

Many, A. and Roberts, J.M. (1997): Increased xanthine oxidase during labour--implications for oxidative stress. Placenta, 18(8): 725726.

Megahed, G.A.; Mamdouh, M. Anwar and El-Ballal, S.S. (2002): Superoxide dismutase. Nitric oxide and lipid peroxide productions and it's relation to apoptotic changes and serum progesterone hormone level during physiological lifspan of Buffalo's corpora lutea. Minufyia Vet. Med. J. 2, (1) 99-112.

Meister, A. and Anderson, M.E. (1983): Glutathione. Annu. Rev. Biochem. 52, 711-760.

Misra, H.P. and Fridovich, I. (1972): The role of superoxide anion in the autooxidation of epinephrine and a simple assay for superoxide dismutase. J. Biol. Chem. 247 (10): 3170-3175.

Murdoch, W.J. (1998): Inhibition by oestradiol of oxidative stressinduced apoptosis in pig ovarian tissues. J. Reprod Fertil., 114(1): 127-30.

Palmer, J.H. and Paulson, K.E. (1977): Reactive oxygen species and antioxidants in signal transudation and gene expression. Nutrition Rev. 55, 353-361.

Riley, J.C.M. and Behrman, H.R. (1991): Oxygen radicals and reactive oxygen species in reproduction. Proceeding of the society for experimental biology and medicine. 198, 781-791.

Roche, J.F.; Crowe, M.A. and Boland, M.P. (1992): Postpartum anestrum in dairy and beef cows. J. Reprod. Sci., 28: 371-378.

Sawada, M. and Carlson, J.C. (1989): Superoxide radical production in plasma samples from regressing corpora lutea. Can J. Physiol Pharmacol 67: 465-471.

Sen, C.K. and Packer, L. (1996): Antioxidant and redox regulation of gene transcription. FASEB journal, 10, 709-720.

Smith, R.; Wickings, E.J.; Bowman, M.E.; Belleoud, A.; Dubreuil, G.; Davies, J.J. and Madsen, G. (1999): Corticotropin-releasing hormone in chimpanzee and gorilla pregnancies. J. Clin Endocrinol Metab. 84(8): 2820-5. 
Su, W.; Chang, C.; Peh, H.; Lee, S.; Huang, M. and Zhao, X. (2002): Apoptosis and oxidative stress of infiltrated neutrophils obtained from mammary glands of goats during various stages of lactation. Am. J. Vet. Res. 63: 241-246.

Tilly, J.L. and Tilly, K.I. (1995): Inhibitors of oxidative stress mimic the ability of follicle-stimulating hormone to suppress apoptosis in cultured rat ovarian follicles. Endocrinology 1995 Jan 136:1 242-252

Toescu, V.; Nuttall, S.L.; Martin, U.; Kendall, M.J. and Dunne, F. (2002): Oxidative stress and normal pregnancy. Clin Endocrinol (Oxf), 57(5): 609-613.

Yaacobi, N.; Ohel, G. and Hochman, A. (1999): Reactive oxygen species in the process of labor. Arch Gynecol Obstet. 263(1-2): 23-4.

Yoshida, M. (1993): Role of glutathione in the maturation and fertilization of pig oocytes in vitro. Mol. Reprod. Dev. 35, 7681. 